\title{
CULTURAL DETERMINANTS OF CREATING MODERN ORGANISATIONS - THE ROLE OF TRUST
}

\author{
W. M. Grudzewski \\ Warsaw School of Economics, Collegium of Business Administration \\ Correspondent Member of Polish Science Academy, POLAND \\ w.grudzewski@orgmasz.pl \\ I. K. Hejduk \\ Warsaw School of Economics, Collegium of Business Administration, POLAND \\ ihejdu@sgh.waw.pl \\ A. Sankowska \\ Warsaw University of Technology, Faculty of Production Engineering, POLAND \\ e-mail: amsankowska@wp.pl \\ M. Wańtuchowicz \\ Warsaw University of Technology, Faculty of Production Engineering, POLAND \\ e-mail: monika.wantuchowicz@wp.pl \\ The virtual form of organisation is the answer for turbulent and highly \\ competitive environment and rising demands of customers. However, the \\ theory of virtual organisation (VO) is still evolving and being systematized, \\ similarly to its practice. Therefore, there is a focal quest to determine the \\ conditions and circumstances favourable to creating VO. It appeared in the \\ author's research that trust in general and trust management particularly \\ plays the significant role in VO. The article explores the cultural determinants \\ of $V O$ and provides the examples of Swedish and American culture.
}

\section{INTRODUCTION}

The twentieth-first age requires adapting new organisational forms for cooperation. This is the consequence of continuous changes in turbulent and competitive environment as well as more and more demanding clients (Grudzewski, Hejduk, Sankowska and Wańtuchowicz, 2007). Many authors underline the significant role of trust in relations based on cooperation (e.g., Casson 1991, Dasgupta 1988, Gambetta 1988, Handy 1995, Lorenz 1988, Ring and Van de Ven 1992). By researchers, trust is perceived as the focal point for further discussion on components that contribute to the success of modern organisations (different forms of collaboration, e.g.: strategic alliances, and partnering networks of small- and medium-sized companies).

Virtual organisation (VO) is frequently in the centre of attention among theoreticians and practitioners of management. Currently the coherent theory is being built. Therefore, there appear many questions that still need to be answered. One of them is of focal meaning: what are the conditions necessary for creating $V O$ ? Cultural determinants are believed to be crucial. Hence, it is not surprising that 
VOs are present and active in some countries, cultures more often that in others. The United States of America and Sweden has been carefully selected to illustrate the case of VO's cultural determinants. Nota bene, Swedish organisations are said to be the most trustworthy all over the world (Edelman Trust Barometer, 2007). This fact is meaningful because trust is nowadays recognized as crucial and economically measurable value (Lewicka-Strzałecka, 2003). At this juncture we shall ask: how Swedish organisations achieve so high level of trust? And why American organisations having similar cultural determinants are confronted by growing trust deficit? Finally, we can infer a conclusion of great worth for other organisations all over the world - crucial for their further functioning and development. This paper is supporting the following thesis: trust management applied in practice allows to improve the performance of organisation, above all the performance of $\mathrm{VO}$.

In this paper, we explore the cultural determinants and its importance for creating modern organisational forms - VOs in Sweden and the US. The starting points are results of our research as well as opinions of four authorities in cultural management - Charles Hampden-Turner, Fons Trompenaars, Geert Hofstede and Gert Jan Hofstede. The implication is that national culture characterizes the attitude to the category of trust.

The analysis of our results will consequently but also indirectly give the answer for the following question: what kind of culture stimulates and fosters creating as well as functioning of modern organisations, most notably VOs? Firstly, we will explore the specific features of both cultures - American and Swedish ones. Secondly, on the basis of our results, we will discuss the critical success factors (CSF) for creating and functioning VOs in the context of cultural determinants. We will present the visible and invisible impact of culture and culture dimensions on creating VOs in particular. In our empirical and theoretical discussion we will bring forward different opinions on the superiority of information and communication technologies (ICT) over culture with reference to VO functioning.

\section{SWEDISH CULTURE VERSUS AMERICAN CULTURE}

\subsection{Organisational culture and trust management}

Culture determines the patterns of behaviors, defines situations and their perception. It diversifies the view of the world and actions taken by individuals (organisations). Among theoreticians as well as practitioners there is disagreement about the importance of technology and culture. On the one hand, technology is considered as the hard core of every organisation. On the other hand, technology and its products are said to contribute to any fundamental value changes. However, we strongly believe that culture creates the context for technology. Organisational changes rather refer to applied practices (Hofstede and Hofstede, 2007, p. 25). In those circumstances, exploring culture in $\mathrm{VO}$ is well-grounded and required (see Figure 1). 


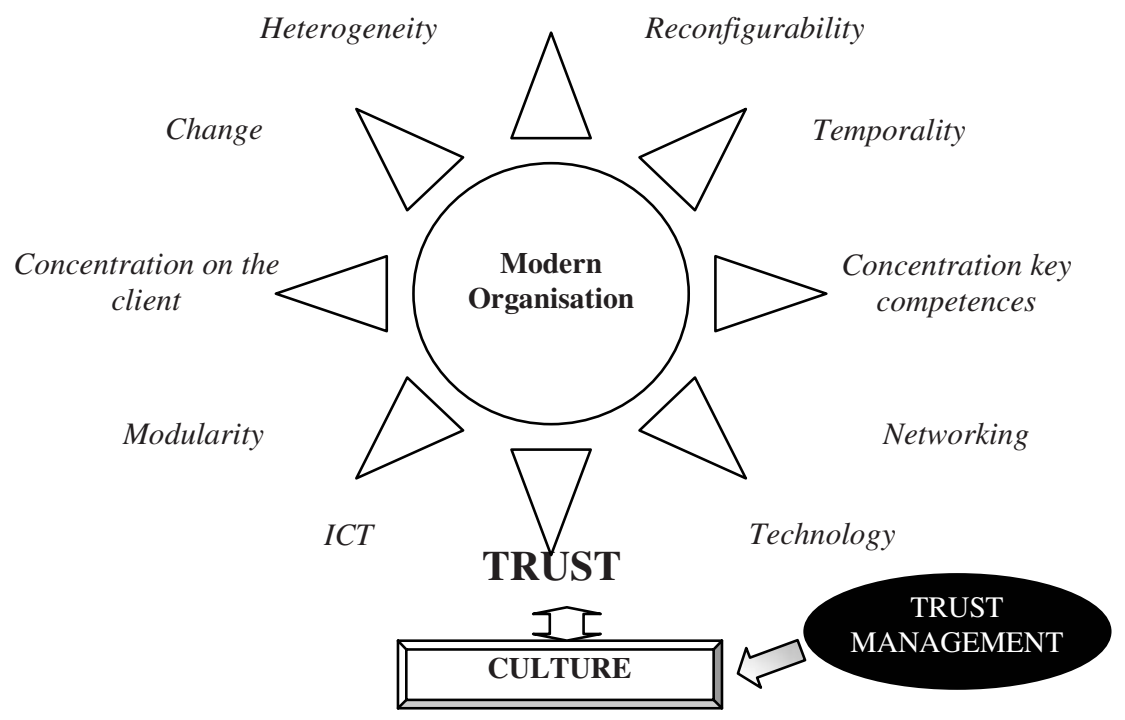

Figure 1 - Characteristics of modern organisation via culture

There are at least eleven features of the modern organisation (see Figure 1). Trust determined by culture is an unambiguous characteristic of virtual collaboration in the light of existing theory as well as empirical results from real VOs (see e.g.: Handy, 1995, Grudzewski, Hejduk, Sankowska and Wańtuchowicz, 2007). Therefore, there is no doubt about the rising role of the most recent management method - trust management - initiated and disseminated in management sciences by Grudzewski, Hejduk, Sankowska and Wańtuchowicz $(2007,2008)$.

\subsection{Characteristic of Swedish and American cultures}

According to French sociologist Pierre Bourdieu culture is collective programming of the mind that allows to distinguish members of one specific group or category of people (Hofstede and Hofstede, 2007, p. 17). Culture profile is similar in Sweden and the USA. The wealth hoarding system is based on universalism, analysis, individualism, external controllability, gained status, equality and sequentiality. Swedish culture is bearing a close resembling to American one in six from seven categories. The only difference is in control location: internal or external. External controllability of Swedes is coming from their strong dependence on nature, severe climate and export.

In principle, Swedish and American cultures are two most similar cultures in comparison to other cultures (Hampden-Turner and Trompenaars, 2006/1993). Table 1 presents the wealth building values in Sweden, the US and other countries according to Hampden-Turner and Trompenaars ${ }^{1}$ (2006/1993):

\footnotetext{
${ }^{1}$ Different classification was proposed by Hofstede: power distance (from small to large), collectivism individualism, femininity - masculinity, avoidance of the uncertainty (from weak to strong).
} 
Table 1 - Seven dimensions of culture in different countries according to Hampden-

Turner and Trompenaars

\begin{tabular}{|c|c|}
\hline INDIVIDUALISM & COLLECTIVISM \\
\hline $\begin{array}{l}\text { personal freedom, human rights, } \\
\text { competitiveness }\end{array}$ & $\begin{array}{l}\text { social responsibility, harmonious relations, } \\
\text { collaboration }\end{array}$ \\
\hline The United States, Sweden & France, Japan, Germany \\
\hline SEQUENTIALITY & SYNCHRONOUSNESS \\
\hline $\begin{array}{l}\text { keeping with scheduled course } \\
\text { The United States, Sweden }\end{array}$ & $\begin{array}{l}\text { tasks coordinating } \\
\text { Japan, France }\end{array}$ \\
\hline GAINED STATUS & ASCRIPTIONS STATUS \\
\hline $\begin{array}{l}\text { what we did, our results } \\
\text { The United States, Sweden, Germany }\end{array}$ & $\begin{array}{l}\text { who we are, our potential, connections } \\
\text { France, Japan }\end{array}$ \\
\hline UNIVERSALISM & PARTICULARISM \\
\hline $\begin{array}{l}\text { rules, codes of law and generalization } \\
\text { The United States, Sweden, Germany }\end{array}$ & $\begin{array}{l}\text { exceptions, special conditions, unique relations } \\
\text { France, Japan, Germany }\end{array}$ \\
\hline FRAGMENTATION & ENTIRENESS \\
\hline $\begin{array}{l}\text { atomization, reduction, analysis, objectivism } \\
\text { The United States, Sweden }\end{array}$ & $\begin{array}{l}\text { holism, polishing, synthesis, relation ability } \\
\text { France, Japan, Germany }\end{array}$ \\
\hline INTERNAL CONTROLLABILITY & EXTERNAL CONTROLLABILITY \\
\hline $\begin{array}{l}\text { conscience and internal beliefs } \\
\text { The United States, France, Germany }\end{array}$ & $\begin{array}{l}\text { patterns and factors influencing from outside } \\
\text { Sweden, Japan }\end{array}$ \\
\hline EQUALITY & HIERARCHY \\
\hline The United States, Sweden, Germany & France, Japan \\
\hline
\end{tabular}

Individualism characterizes individuals that build loose relationships, concentrating on themselves and their families (Hofstede and Hofstede, 2007, p. 88). Swedish individualism is very unique and differs a lot from American one. Swedes are individualistic, aware of their own identity, exceptionality, freedom, aspirations and values and in the same time they are modest and aware of their social duties. They emphasize that source of their own satisfaction and destinies are support and help in development of others. They perfectly deal with dilemma of bringing together individualism with social duties. Moral rights are understood like voluntary agreement denominating rules of conduct and cooperation. Hampden-Turner and Trompenaars (2006/1993) call this socialized individualism.

Swedes and Americans represent sequential culture. It means a race against time. Tasks need to be done faster and faster, using high-tech machines and production lines. In this context, VO - ad hoc form of collaboration created dynamically, in short period of time - beyond doubt is the best solution.

Logic of building virtual collaboration is founded on equality of partners. It is assessed via its results, using category of achievements. Universalism warrants acceptance as well as dissemination of framework of reality view, regardless of situation and particular interests - which in new alliances secure acknowledgement of rules and norms as binding - and recognizing all collaborants equally regardless of their group affiliation. As a consequence, activities become more predictable. Rejecting hierarchy, injecting equality are promoting trust in accordance with theory of "liking those who are similar to ourselves" (Grudzewski, Hejduk, Sankowska, Wańtuchowicz, 2007) what was confirmed in the last survey by Edelman in 2007. Particularism interprets activities differently according as groups to which individual belongs to. Furthermore, it conduces to building trust in small group to which belongs individual (e.g.: family, mafia, organisation clique) and mistrust 
towards individuals from other groups. Social trust originates from universalism while particular trust from particularism (see Figure 2).

Equality between collaborants is crucial issue for building trust atmosphere. Employees tend to trust people similar to themselves rather than CEO. Simple worker are granted higher level of trust than CEO. Outsiders, for instance: financial analysts, scientific and didactic workers, win high level of trust (Edelman, 2007). It has focal meaning when building effective leadership, internal as well as external communication plan.

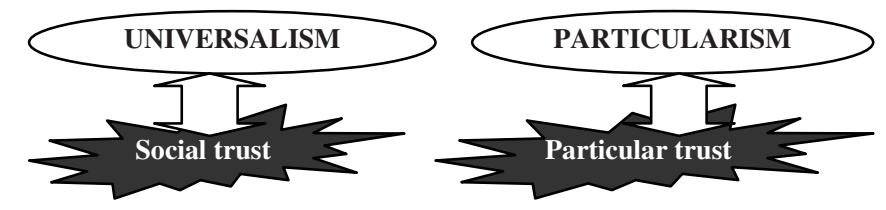

Figure 2 - Two different types of trust induced by universalism and particularism

It becomes visible that Americans and Swedes belong to different cultures which are characterized by high level of trust. They can be described as trust cultures - in society there are common rules that impose to recognize trust and reliability as values, trust in others and meeting the obligations as norms of appropriate conduct (Sztompka, 2007). In other words, we can generally trust others.

Trust is believed to be the critical success factor in the opinion of Swedish and American experts according to research by Grudzewski, Hejduk, Sankowska and Wańtuchowicz in 2006 and 2007 (see Figure 3). The most important CSFs are: honesty and clearness of communication (Swedish experts) and trust (American experts). At first glance the results seem to be totally disparate. Nevertheless, careful analysis leads us to modus vivendi between those two indications. Honesty and clearness of communication is the focal element of trust building process, precondition of trust atmosphere between collaborating parties (more details: Grudzewski, Hejduk, Sankowska and Wańtuchowicz, Zarządzanie zaufaniem w organizacjach wirtualnych, 2007 and Trust Management in Virtual Work Environments: A Human Factors Perspective, 2008). Trust management (Grudzewski, Hejduk, Sankowska and Wańtuchowicz, 2008, p. 37) covers the activities of creating systems and methods that:

1. Allow relying parties to make assessments and decisions regarding the dependability of potential transactions involving risk

2. Allow players and system owners to increase and correctly represent the reliability of themselves and their systems.

The highest rank was given to communication issues from strong deeprootedness of trust in Swedish culture. Swedish culture belongs to the one of the most trusting cultures all over the world. It is corroborated by for example the roots of word trust that is probably of Scandinavian origin, akin to the Old Norse traust (Grudzewski, Hejduk, Sankowska and Wańtuchowicz, 2008, p. 22). 


\subsection{Critical success factors ranking by Swedish and American experts}

Hence, we can ascertain that trust is part of Swedish culture foundation. In the same time, in American culture trust is derived from trust to law institution. Therefore, we assume that the best patterns of trust can be drawn from Scandinavian culture where trust is rather a culture norm than a law norm. Furthermore, it probably influenced penal code that we lighter compared with other countries. In cultures with lawrooted trust the first factors stopping from breaking the law are harshness and inevitability of a punishment. It is not surprising that the last survey by Edelman in 2007 announced that Swedish organisation are the most trustworthy all over the world.

A survey was conducted among American and Swedish experts experienced in intercollaboration. From 48 initial factors that are believed to impact the decision to select or not select a partner for a potential VO, trust received the highest sum of ranks given by experts. Each factor could receive 44 points maximally. Trust was ranked highest among 10 critical success factors for VOs with the highest sum of ranks.

The experts' survey (see Figure 3) allows us to indicate rare supplies based on the ranking of the CSFs. Moreover, we concede that American and Polish cultures are characterized by the scarcity of trust comparing to Swedish one. Consequently, it is rare supply in economy ${ }^{2}$.
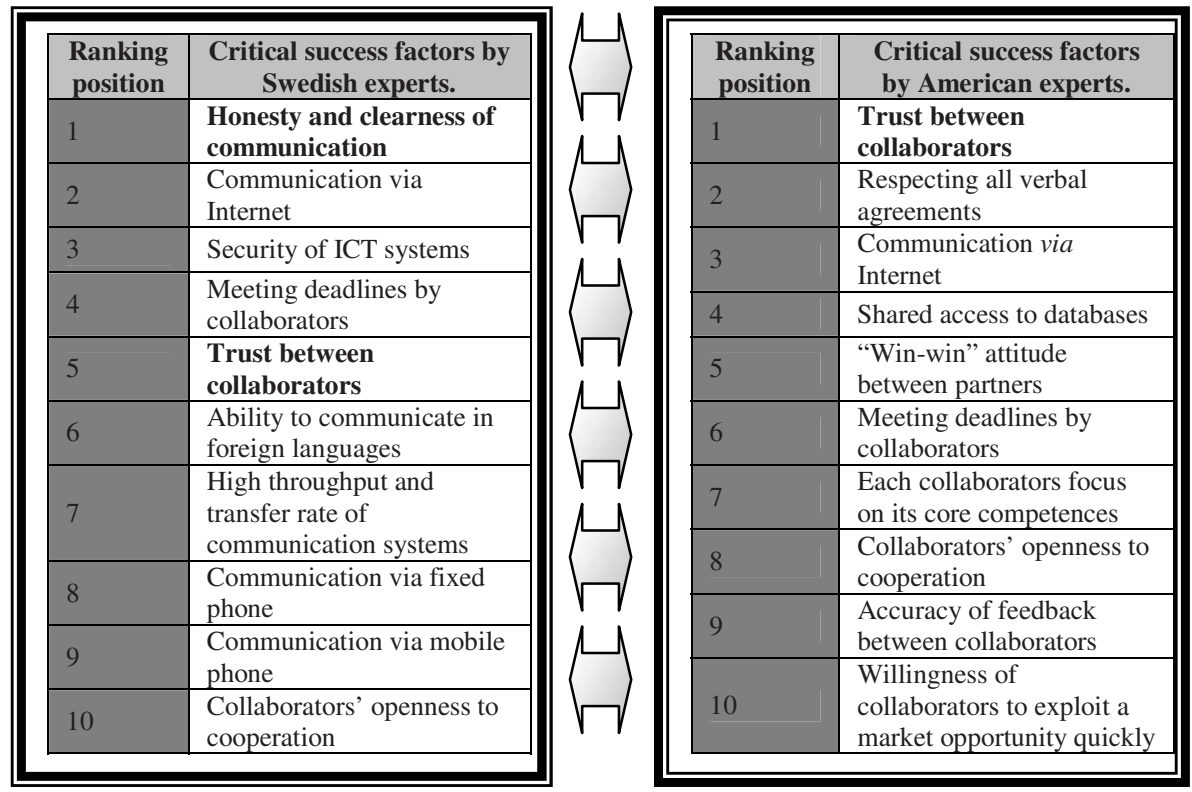

Figure 3 - The significance of specific VO critical success factors by Swedish and American experts (Grudzewski, Hejduk, Sankowska and Wańtuchowicz, 2007, 2008).

\footnotetext{
${ }^{2}$ Trust is indicated as the most important when building collaboration between enterprises in IT Polish sector (see: Grudzewski, Sankowska and Wańtuchowicz, 2005).
} 


\subsection{Trust culture versus other elements of culture}

At this point, we can raise the following question: how trust is related with other elements of culture? Trust is understood as a "bet" (belief and, based on it, activity) that future activities of other people or functioning of the devices or institutions will be advantageous to us (Sztompka, 2007, p. 99). It is a new type of specific, unique and precious capital that influences the economic performance of organisations and societies. Trust predisposes to the role of the strategic supply in organisation because it easily undergoes the following tests: (Grudzewski, Hejduk, Sankowska and Wańtuchowicz, 2008, p. 21): value test (trust helps organisations adapt to dynamic changes in turbulent environments), rarity test (high levels of trust are nontangible assets in only some organisations), ownership test (interpersonal trust is seen as specific "employee's corporation" because it can be observed in a certain employee), imitation test (trust is highly resistant to imitation or automatic copying), resistance test (when creating trust with time, there is a tendency to trust growth), substitution test (trust cannot be replaced with other utilitarian value because it is the driving force for new culture norms), competitiveness test (trust can form the basis for the highly competitive action strategy), formalization test (trust cannot be created through administrative regulations and codified organisation rules), organisation test (trust practically contains all aspects of enterprises' functioning).

Scientific attitude to problem solving is linked with trust between people (Bjerke, 2004/1999). It is the result of universalistic attitude of science to encountered problems and then it secures predictability of activities and reactions. Traditional attitude results from lack of trust (see Figure 4). Forasmuch, trust and science coincide with each other. Consequently, their synergetic effect conveys generous benefits. Further on, VO - that is always grounded on trust notwithstanding its dynamic form can solve rational problems. Therefore, VO can exist only in cultures that value trust greatly. In other cultures traditional attitude to problems solving denies VO.

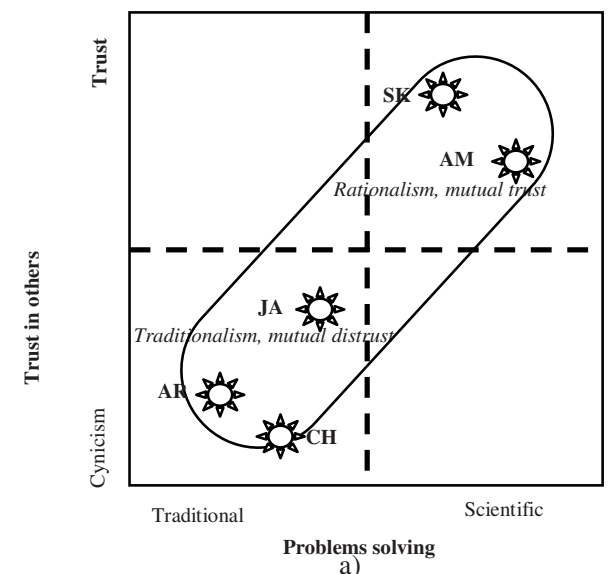

AM - American culture, AR - Arabic culture, JA - Japanese culture, $\quad$ SK - Scandinavian culture.

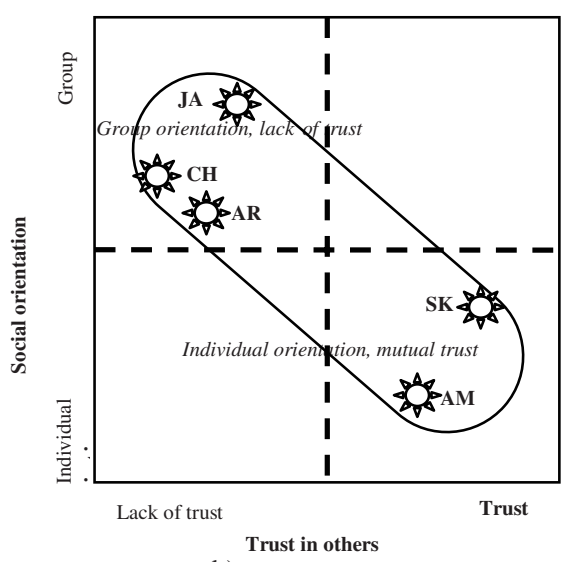

b)

$\mathrm{CH}$ - Chinese culture,

Figure 4 - Direct and permanent dependences between level if trust and: a) methods 
of solving problems b) types of social orientation (Bjerke, 2004, p. 258-259)

Individualistic social orientation means that people trust in each other (Bjerke, 2004/1999, p. 257). It is remarkable fact that group orientation is followed by lack of trust in other group members. In practice, it implies that the role of equal chances and social agreement appreciating individualism grows in societies and environments. Strong equality can be seen in almost everything, and this has made it easier to create less formal, more delegating styles of management in Swedish organisations. The interpersonal friction between managers and workers is reduced all employees expect to have a say and Swedish organization itself is seen as an organism for creativity and innovation and the learning process is highly appreciated. In the same time, position in hierarchy, strong sense of duty and sometimes consensus are highly valued in societies and environments oriented on group like Sweden.

We commit a mistake presuming that individualism supporters do not take care about the society development, e.g. Americans founded more voluntary associations than any other nation (Trompenaars and Hampden-Turner, 2004/1993). Therefore, we profess our opinion that individualistic societies can create VO because there is no distrust, no negation against strangers and consequently higher ability to sign new agreements.

People from culture with high level of trust do deal perfectly in the situation of uncertainty or lack of order (Bjerke, 2004/1999, p. 261). It is said that trust is a strategy of dealing with uncertainty. Hence, it is not surprising that Swedes are famous for low uncertainty avoidance index (UAI). Avoiding uncertainty describes the level of threat perceived by members of certain culture in the face of new, unknown situation (Hofstede and Hofstede, 2007/2005, p. 181). Culture of mutual cynicism, mistrust entail formal legal remedies.

Trust is a value and determines the success of transaction in trust cultures. It is a stimulator of human activities. In such cultures we can observe social well-being and economic growth in the opinion of Fukuyama (1995). In cynicism cultures those who trust are said to be naive. They often are victims of dishonest behaviors. Cynicism induces the increase in transactional costs and limits the freedom of activity, collaboration, cooperation, communication, it divides people. Trust does not perform its functions in cynicism culture because it becomes depreciated. Doubtless VO as form of collaboration can be more common and prevalent in trust cultures.

According to IBM survey by Hofstede and Hofstede (2007/2005) Swedish culture characterized the lowest masculinity index all over the world. Therefore, it belongs to so-called feminine cultures. This culture is distinguished by sensitive and protective values and care about the quality of life.

\section{CONCLUSIONS AND SUGGESTIONS FOR FUTURE RESEARCH}

The role of trust in modern organisation especially in $\mathrm{VO}$ is enormous. This generates the need for trust management. It is crucial issue for every organisation 
nowadays. Our research confirmed the thesis about focal role of trust for creating VO. This cultural determinant was denoted by American and Swedish experts.

Discussion about the cultural dimensions favorable for creating VO can be conducted not only on the national level but also on organisational level. The knowledge about the influence of certain culture dimensions can be the guideline on creating cooperation suitable for modern virtual collaboration. It can be the implication for organisation building trust that improves its results. The importance of trust in cooperation is crucial for enterprises, especially in dynamic sectors. Alarming is lower trust in CEO comparing to line workers. This is a signal that there is a need to rebuild cognizant and carefully directed leadership.

Multicultural enterprises where employees have different cultural background meet a particular challenge. There is a tendency to place trust and consequently high asymmetry in attitude to trust. Finally, in order to build VO and trust on macro (national) level and micro (organisational) level, we need: socialized individualism, universalism in work processes and operational rules, equality, scientific attitude to problem solving, law level of avoiding the uncertainty, clearness of activities.

\section{REFERENCES}

1. Bjerke B. Kultura a style przywództwa. Zarządzanie w warunkach globalizacji. Oficyna Ekonomiczna, Kraków 2004.

2. Casson M. The economic of business culture: Game theory, transaction cost, and economic performance. Oxford: Claredon 1991.

3. Dasgupta P. Trust as commodity, [in:] Gambetta D. (ed.): Trust: Making and breaking cooperate relations, Oxford: Blackwell 1988.

4. Edelman Trust Barometr 2007.

5. Fukuyama F. Trust: The social virtues \& creation of prosperity, The Frez Press, New York 1995.

6. Gambetta D. Trust: Making and breaking cooperate relations. Oxford: Blackwell 1988.

7. Grudzewski WM, Hejduk IK, Sankowska A, Wańtuchowicz M. Zarządzanie zaufaniem w organizacjach wirtualnych, Difin, Warszawa 2007.

8. Grudzewski WM, Hejduk IK, Sankowska A, Wańtuchowicz M. Trust Management in Virtual Work Environments: A Human Factors Perspective, Series: Ergonomics Design \& Mgmt. Theory \& Applications Volume: 2, Taylor \& Francis CRC Press, 2008.

9. Grudzewski WM, Sankowska A, Wańtuchowicz M. Virtual Scorecard as a decisionmaking tool in creating Virtual Organisation, [in:] Camarinha-Matos L. M., Afsarmanesh H., Ortiz A. (eds.): Collaborative Networks and Their Breeding Environments, series International Federation for Information Processing (IFIP), the Kluwer Academic Publishers - Springer, USA-Norwell, 2005, pp. 293-300.

10. Hampden-Turner Ch, Trompenaars, A. Siedem kultur kapitalizmu, USA, Japonia, Niemcy, Francja, Wielka Brytania, Szwecja, Holandia, Oficyna Ekonomiczna, Kraków 2006.

11. Handy Ch. Trust and virtual organization, Harvard Business Review, May-June 1995.

12. Hofstede G, Hofstede GJ, Kultury i organizacje, Polskie Wydawnictwo Ekonomiczne, Warszawa 2007.

13. Lewicka- Strzałecka A. Zaufanie w relacji konsument -biznes, Prakseologia, nr 143, s. 195-207.

14. Lorenz EH. Neither friends nor strangers: Informal networks of subcontracting in French industry, [in:] Gambetta D. (ed.) Trust: Making and breaking cooperate relations. Oxford: Blackwell 1988. 
15. Ring PS, and Van de Ven AH. Structuring cooperative relationships between organizations, Strategic Management Journal, 13(7), 1992, pp. 483-498.

16. Sztompka P. Zaufanie. Fundament Społeczeństwa, Znak, Kraków 2007.

17. Trompenaars F, Hampden-Turner Ch. Siedem wymiarów kultury, znaczenie różnic kulturowych w działalności gospodarczej, Oficyna Ekonomiczna, Kraków 2002. 